\title{
THE EFFECTIVENESS OF USING AUTHENTIC MATERIALS IN TEACHING DESCRIPTIVETEXT TOWARD WRITINGABILITY
}

\author{
${ }^{(1)}$ Ilham, M.Pd, ${ }^{(2)}$ Rina Mariana \\ (1) Lecturer of English Department University of Muhammadiyah Mataram \\ (2) Student's of English Department University of Muhammadiyah Mataram
}

\begin{abstract}
This research is intended to find out the effectiveness of using authentic materials in teaching descriptive text toward students' writing ability. This study was conducted in MTs. Nurul Jannah NW Ampenan. There were two classes of eight grade students with each class were 20 students. So, the total numbers of students in eight grade of MTs Nurul Jannah NW Ampenan were 40 students. The writer took class A as experiment group and class B as control group. The experimental group was treated by using authentic materials and the control group was treated without authentic materials. Before giving instructions, two groups were given pre-test. After that they were given post-test. The result showed that the mean score of experimental group was 28 and the mean score of control group 7,25. The standard deviation of experimental group was 2363 and the standard deviation of control group was 173,75. The final result obtained through analysis of the data was the value of t-test 8,042. This consulted to the value of t-table which was $2,750<(8,042>2,750)$. It indicated that the value of t-test was higher than the value of t-table. It meant that, an authentic material was effective in teaching descriptive text toward students' writing ability.
\end{abstract}

Key words: authentic material, descriptive text, writing skill.

\section{INTRODUCTION}

In teaching English, there are four skills should be mastered by the learner such as: listening, reading, writing, and speaking skill. All of them cannot be taught separately, but must integrate in teaching process at once. From those four skills, writing is very important to learn since. As we know, Writing is not easy. Among the skills, writing is the most difficult skill to be learn, because it needs hard thinking in producing word, sentence, and paragraph at the same time.

Writing is the most difficult skill for second language learners to master (Richard, 2002:303). The difficulty lies not only in generating and organizing ideas, but also in translating those ideas into readable text. In the second year of junior high school, the basic competency that should be achieved in the writing English subject is 
that the students have ability to develop and produce written simple functional text in descriptive, narrative, report and procedure text which is called genre.

Descriptive text is one of the function text which is difficult enough to be learn by the students (Artono Wardiman, 2008:115). Descriptive text is a text that describes the character, and description is the part of pharagraph that describes the character. The students can use the simple present in writing descriptive text. In writing the descriptive text, students often fine some difficulties. The students usually have difficult to organize their ideas. Furthemore, many students made some mistakes and face difficulties to build and develop their imagination because, the students lack of vocabulary, they do not know how to organize their language in a senteces and than they have less of references. So those all problems faced by students in composing writing text.

From the problems explain above, the writer tries to offer one alternative technique using authentic materials which is significant to increase student's imagination. One of the advantages using authentic materials is learner would be more creative approach in teaching especially in teaching English by using media (Philip \& Shettlesworth 1978; Clark 1989; Peacock 1997, cited in Zurkarnain: 2014). Authentic materials in the teaching learning of writing process is expected giving significant result, so that gradually, the student's abilities in developing their competences of writing shows meaningful progress.

There are some studies related with the use of authentic materials in learning writing. First, Sacha Anthony Berardo's entitled “ The Use of Authentic Materials in Teaching of Reading" (2006), he found that using authentic material has positive aspects. The students have highly motivation, giving sense of achievement when understand and encourage further reading. The next study, Wirman Kanta Prawira's entitled "The Use of Authentic Materials Towards Students' Ability in Comprehending of Procedure text for The Third Grade of SMP Salafiyah Darul Falah in School year 2012/2013" (2012), he found that there is an affect of the use of authentic materials toward students' ability in comperending of procedural text.

The last study, written by Nurul Wahyuningsih Putri (2009), the thesis entitled "The Effectiveness of Using Picture Series in Writing Descriptive Paragraph: A case study at the second year student of SMP Al-Ikhlas Taliwang Academic year 2008/2009", English Education Departement, Faculty of Teacher Training And Education Muhammadiyah University of Mataram. Where the result is the using picture series in teaching writing gives positive effect in helping students to express ideas in writing skill.

Based on the situation the researcher interested to investigate a research entitled "The Effectiveness of Using Authentic Materials in Teaching Descriptive Text Toward Student's Writing Ability at the Eight Grader of MTs. Nurul Jannah NW Ampenan in Academic Year 2014/2015.

The research question of this study is formulated as follow: 
1. Is authentic materials effective in teaching descriptive text toward students' writing ability at the eight grades of MTs. Nurul Jannah NW Ampenan in Academic Year 2014/2015?

\section{REVIEW OF RELATED LITERATURE}

\section{Concept of Writing}

Writing is an integrated skill in English learning language. It is a process to learn English. Writing is the representation of spoken language, written language is almost same with spoken language,the difference is the performance of written language is conveyed in graphical. Brown (2001 :335) mentioned that written product are the result of thinking, drafting, and revising procedures, specialized skills is required in written language, and not every speaker develops naturally. Nunan (2003: 88) also give other ideas that : writing is the process of thinking to invent ideas, thinking about how to express into good writing, and arranging the ideas into statement and paragraphclearly. It indicated that the learners are expected to explore the ideas and make them into good written.

Moreover, in order to write a good written product, learner should follow some steps such as writing, drafting, brainstorming and revising. As Brown ( 2001 : 335 ) stated that written products are often the result of thinking, drafting, and revising procedures that required specialized skill, skill that not every speaker develops naturally. Another definition by Meyers (2005:2) says writing is an action, a process of discovering and organizing your idea, putting them on paper and reshaping and revising them.

Based on the theories above of writing, it can be concluded that writing is the process of thinking to invent ideas, about how to express the ideas into good writing and arrange the ideas into statement and paragraph clearly. It is indicated that the learners are expected to explore the ideas and make them into good written. The scoring is based on indicators of writing competence, namely organization, content, grammar, punctuation, spelling, mechanics, style and quality of expression.

\section{The Roles of Teaching Writing}

Writing is one of four language skills that are tought to students who study language generally and study English specially. In teaching writing, teachers can train, motivate their students to use what their students have fully, such as: ideas, messages, felling, expectations, and language they master.

However, writing is not only need to competence of students to find and to express their ideas but also need students' competence to use good and correct grammar. Lack of grammatical mastery such as the use of simple present tense in descriptive text can cause problem in writing.

In giving writing exercise, it is better for teacher to pay attention to what his students do, to help them if they find problems in looking for and finding ideas, to express ideas, 
and language use. Because writing is important to students, it is better of teacher to rise and to maintain students' interest to write and to make writing as natural and enjoyable occupation (Julianto, 2010:23).

Based on statement above, the role of teacher in the classroom is central to help students become strong writers. Regardless of the content that teacher teach, students can write to convey what they know. When you integrate reading and writing, use writing-to-learn, provide students with substantive feedback, and use exemplary examples in your classroom, students become better writers (Vicki \& Monette, 2005: 71).

Moreover, the teacher can so dispose the class that writing becomes natural and enjoyable occupation.

\section{Classroom Technique in Teaching Writing}

Since writing as aprocess is oriental towards work in progress and the development of new skills, rather than merely evaluative tasks, the classroom practices, therefore will vary from each other. These often depend much upon the students' experiences and skills when planning and adjusting their writing program. However, when this new paradigm is applied into classroom practice, certain characteristics should be well recognized. Some of the characteristics described by Endang Fauziati (2008:145) are as follow:

1. Instruction should be focused in writing process. This mean that students can intiate into the process, and the teacher shoukd prepare to interverence in the students' writing processes with suggestions, and correction to help the students overcome difficulties encountered in each of the stage.

2. The assigned writing tasks should encourage students to write a variaty of the modes besides expository writing. This is based on understanding that people do use different modes of writing and they do require different process.

3. Converencing is an important part of the classroom activity. It occur between teacher and students as well as between students. Such an activity provides students with immediate, meaningful responses to their writing. This will develop students' ability to reflect upon their own writing and the writing of other in a critical and constructive way (Brown, 1994).

4. The main role of the teacher is as a facilitator. The teacher no longer focuses just on error in the product, but is free to respond a number of facets of students' writing. This may include understanding and giving nice responses to what the students is writing.

5. Since the teacher's role is as a facilitator and students would work and help each other, rather than work alone or just with the teacher, the classroom would be arrange in the manner of a workshop, where students can work in pair, or groups. The students, therefore, eventually realize thet writing generally require many drafts and revisions to get ideas into a form of writing.

6. A bond which ties all members of the class into one community, whose member feels responsible for each other's growth, can be created in such classroom. This 
sence of a community, of oneness, in turn, can provide a risk-talking environment which is very important for learners to be able to grow to their maximum potency.

From the technique above, the writing as a process have made the class exploratory and more effective for the students to develop their writing skill. They have become more humanistic, more friendly, and more fun. Students and teachers work together and colaborate; they become more relaxed. This is a way to increas interest in writing a process. Which the students need so much attention how good to write.

\section{Concept of Decriptive Text}

Descriptive text is a part of factual genres. Its social function is to describe a particular person, place or thing (Atono Wardiman, 2008: 122). Description in writing is the process of creating visual images and sensory impression through word. More often, description is a part of another piece of writing and using to inform an audience about how something or someone loooked or to persuade an audience to see something from the writer's point of view.

Description recreates sense impression by translating into words, the feel, sound, taste, smell and look of things. Emotion may be describing too, feeling such as happiness, fear, loneliness, gloom, and joy. Description help the readers, through his or her imagination, to visualize a scene or a person, or to understand a sensation or an emotion.

\section{The Structure of Descriptive Text}

\section{a. The generic structure of desriptive text}

1. Identification: identifies the phenomenon to be described

2.Description of features: contains the explanation / description of the thing or person to mention a few properties..

\section{b. The generic features of description are:}

1. Verb in the simple present tense

2. Adjective to describe the features of the subject

3. Topic sentence to begin paragraphs and organize the various aspects of the description.

\section{Purpose of Descriptive Text}

In social beings, we want to share our experience, so we write to others to describe things such as vacations, childhood homes, and people we encounter. We even use description to persuade others to think or act in particular ways: advertiers products to persuade us to bay them: travel agents describe locales to entice us to visit them: and real estate agents describe properties so stimulate a desire to see them. As the examples in the following chart show, description able us to entertain, express feelings, relate experience, inform, and persuade. 
Table 01. Purpose for Description

\begin{tabular}{|l|l|}
\hline \multicolumn{1}{|c|}{ Purpose } & \multicolumn{1}{|c|}{ Description } \\
\hline To express feelings & $\begin{array}{l}\text { Description of your favorite } \\
\text { outdoor retreat so your reader } \\
\text { unndestand why you enjoy it so } \\
\text { much. }\end{array}$ \\
\hline To relate experience & $\begin{array}{l}\text { A description of your childhood } \\
\text { home to convey a sence of the } \\
\text { proverty you grew up in. }\end{array}$ \\
\hline $\begin{array}{l}\text { To inform (for a reader unfamiliar } \\
\text { with the subject) }\end{array}$ & $\begin{array}{l}\text { A description of an apple to help } \\
\text { the reader who has never seen one. }\end{array}$ \\
\hline $\begin{array}{l}\text { To inform (to create a fresh } \\
\text { appreciation for the familiar) }\end{array}$ & $\begin{array}{l}\text { A description of an apple to help } \\
\text { the reader rediscover the joys of } \\
\text { this simple fruit. }\end{array}$ \\
\hline $\begin{array}{l}\text { To persuade (to convince the reader } \\
\text { that some music videos degrade } \\
\text { woman) }\end{array}$ & $\begin{array}{l}\text { A description of the degrading } \\
\text { music, videos. }\end{array}$ \\
\hline To entertain & $\begin{array}{l}\text { An amusing description of } \\
\text { teenager's bedroom. }\end{array}$ \\
\hline
\end{tabular}

Although it can serve a variety of purposes, description is most often expressive, so it most often help researcher share their perceptions.

\section{The Concept of Authentic Materials}

Authentic materials are one of the learning sources that are used by the teacher in the classroom, authentic materials mean that studying about the text that has been given to student without course book, but the materials are taken from magazine, article or newspaper. Freeman (2000:132) states to overcome the typical problem that students can not transfer what they learn in the classroom to the outside world and to expose students natural language in variaty of situations, adhernts of CLT advocate the use of language. Hitler (2005) says that authentic materials are any texts written by native english speakers for native english speakers.

Authentic materials in the classroom can be motivation for the students, as it adds a real-life element to the students learning experience. Authentic materials is signitificant since it increases student motivation for learning, makes the learner be exposed to the "real" language. Taylor (1994:4) further concludes that the most authentic activity in the teaching and learnning situation is that of metacommunication. Meta-communication is use beyond the concept to describe of what is being communicated. This concept will lead us to affirm that authenticity is validated within the teaching and learning situation. 
This part discusses about the types of authentic materials that consist of authentic text and non-authentic text.

\section{Authentic Text}

Authentic text is a text learned by the students to get the information. Harmer (in Taylor, 1994:6) define authentic text as materials that are designed for native speakers; they are real text and they are designed not for language learner, but for the speaker of the language. Meanwhile, Chavez (1998:276) refers authentic text as text that are not written for language teaching purposes. The real text that are learned by the students embrace all rael-life in daily life. Authentic texts have been defined as real-life texts, not written for pedagogic purpose.

Chavez (1998:274) state that the text that are brought into the classroom for pedagogic purpose they have, arguably, lost of their authenticity. It means that although in the form of the texts are authentic materials, but the materials are taken from the course book, it is not called auhentic materials. Therefore, authentic text are materials that are taken out the materials in the coursebook, such as newspepar, magazine, short story, etc. Authentic text also taken from magazine article, newspaper, cooking recipes, etc.

Authentic text also give the reader's chance to obtain the real information. Extracting real information from a real text in the new or different langguage can be extremely motivated. Therefore, the students have to be motivated and supported to learn by exposing them to the real language ( Guariento \& Morley 2001: 5). They also reflect the changes in language use, as well as give the learners the proof that the language is real and not only studied in the classroom:

Authentic text can be used as a tool of motivating the students because they are used to study the real-life purpose by the real people (taylor, 1994:5). When the teacher gives the real text to the student, they will be more interesting to learn it and by having much interesting, it will lead them to understand the text easier. For instance, a teacher will give the text about the real-life from someone or people's culture. Here, the students will be more motivated in teaching and learning process.

\section{Non-Authentic Text}

Non-authentic text is the materials taken from course-book based on the curriculum. In choosing of material or text, it should be based on the students' ability to know what they want.

The language in non-authentic text is artificial and unvaried, concentrating on something that has to be thought and often contains a series of false-text indicators, which include:
a) Perfectly formed sentence
b) A question using a grammatical structure gets a full answer
c) Repetition of structure (Taylor, 1994:6) 


\section{Superiority of Authentic Material}

There are some factors in choosing authentic reading materials. Taylor (1994:7) gives four main criteria in choosing the texts used in the classroom. They are suitability of content, exploitability, readability, and presentation.

a. Suitability of content

Here, the texts have been learned by the students must be interesting, because it is very important to improve their knowladge. In choosing of material or texts it should be based on the students' ability to know what they want, in this case is learning the real text. For instance, the students learn about "how to keep the healthy".

The text above is relevant with studens' need and the students will be easier to know the authenticity of text learned in the classroom activity.

b. Exploitability

Exploitability is hoe the students increase their competence as reader, how the text are exploited for teaching purpose, what purpose should the text be exploited, and what skill used the text or strategies can be developed by exploiting the text itself (Taylor, 1994:8)

c. Readability

In this case, the texts that have been given to the students are categorized easy or difficult, it depend on the students' understanding about the text. In this case, the teacher will choose the easiest materials, so that the students are able to read and understand the text. For exampe, "how to make a glass of coffee". Then, the teacher gives some kinds of recipes to make it.

Readability is used to describe the combination of structural and lexical difficulty of the text, aswell as to find a new vocabulary and some new grammatical rules. It is impoortant to increase their knowladge in english language as a foreign language.

d. Presentation

In this case, authentic material can be presented with variety of the texts, because the students will be bored when they are dealing with only one subject area. The authentic material can be presented by using pictures, diagrams, photographs, etc. They will have the reader not only to understand the meaning of the text but also how to use them. Of course, here, an antractive text will attract the readers to learn the text better.

\section{Advantages of Authentic Materials}

Some advantages of using authentic materials described by Sirwan (2014) are as follows:

a. Authentic materials have positive effect on learner motivation.

b. Textbooks often do not include incidental or improper english. 
c. Authentic material can produce a sense of achievement, e.g., a brochure on england given to student to plan a visit.

d. Authentic materials can encourage reading for pleasure because they are likely to contain topics of interest to learners, aspecially if students are given the chance to have say about the topic or kind of authentic materials to be used in class.

The other advantage of using authentic materials explained by Hitler (2005). He point out that the advantages of using authentic text in the language learning classroom are:

a. Authentic text can be quick and easy to find.

b. Authentic text can be up to date and topical.

c. It's what students will have to cope with eventually.

d. They have to learn how to cope.

e. There is sense of achievement.

f. There is more of it around that student can help themselve to/ it is easier for student to find.

g. There is more stuff for teachers to choose from

h. You can something find a translation

i. You can compare several versions of the same story

j. Student can follow a story and recycle the vocab

$\mathrm{k}$. They might know the story already, making comprehension and guessing vocabulary much easier.

From adventages above, the students obtain to mastery of descriptive text using authentic materials. In this way, the use of authentic matrials has positive effect for learner's motivation using authentic materials.

\section{Disadvantages of Authentic Materials}

Taylor (1994:18) states that the disadvantages in using authentic materials are difficult to teach language, do not need much vocabulary items, complex language structure, because it comes from the native speaker.

a. Dificullty language

The learners get difficulty in authentic learning, because the language was taken from the real magazine, aricles, newspaper, etc. That are written by the native speaker. Here the learners will use dictonary to understand the text and to get the new vocabulary.

b. Unneeded vocabulary items

In this case, authentic materials are making the list of vocabulary, in order that the students are not confused about the content of the text.

c. Complext language structure 
From the example above, we can get the difference of authentic text and non-authentic text, in which the language structure used are not perfectso that it is difficult to understand, while non-authentic text will be easier to be understood because the structure used are perfect.

\section{METHOD}

The method in this study used a quasi exprimental nonequivalent control group designs; design means there where two groups in the research consiting of experimental and control groups not chose with random. But it used different setting in teaching and learning process (Sugiyono, 2014:114). Therefore, in experimental group, the students gave treatment by using authentic materials in learning descriptive text and in control group the students would not used authentic materials.

Population is one of important element on the research. Its generalized composed of the object / subject that have certain qualities and characterisric are determained by the research to learn and then draw the conclusion (Sugiyono, 2014:117). The population of this research was all of the seventh grades student of MTs. Nurul Jannah NW Ampenan in Academic Year 2014/2015 who have been learning English. There were 40 students divided into two class: VIIIA and VIIIB.

The sample of this study was the eight grade of MTs. Nurul Jannah NW Ampenan in Academic Year 2015/2016. Suharsimi (2006) stated that if the subject was less than one hundred it was better to take all sample as a subject. If the subject was more than one hundred, it can be taken between $10-15 \%$ or $20-25 \%$. In this research, the writer took two classes as the sample. They were class of VIIIA ( an experimental group) and VIIIB (a control group).

In collecting data from the sample, the reseacher would like to apply a pretestwhich given at the beginning of the research to know the previous knowledge of the sample. In this case, the pre-test was given to student to take student score before applying teaching and learning process. The pre-test consisted of two intructions namely the writer asked the students to write descriptive text about "Ampenan Beach" but it must followed by correct generic structure and linguistic features.

In addition, the researcher gave the treatment in the experimental group and control group. The treatment refers to teaching descriptive text for experimental group. In this step the researcher gave different treatment to both groups. The researcher taught English writing descriptive text using authentic materials to experimental group, it aimed to build their knowledge in writing skill, the researcher would not used the authentic materials, in control group. The researcher introduced and gave some information about descriptive text to the students. After that the researcher would like to ask the sudents composed descriptive text, for the example the reseacher would like gave a topic about "Ampenan Beach" and ask to identify and describe about it. 
After that, the reseacher would like asked the students about the meaning of descriptive text, function, purpose and characteristic of descriptive text and than asked them to made descriptive text about people "All Gazali". After that the reseacher as would like gave some clues made the students understand descriptive text with easily. It aims to build the students' knowledge that would like made them try to understand descriptive text.

Finally, Post-test is a test that given after the treatment of using the role of write to know the result of the subject after conducting the treatment. In this research, the test would be presented in the same form of writing text in the pre-test.

The reseacher used a scoring rubric that is stated by Huges (2003:133) to get students' value in writing as follow:

Table 3.1

Scoring Rubric for Writing

\begin{tabular}{|c|c|c|c|}
\hline No & COMPONENTS & RANGE & DESCRIPTION \\
\hline \multirow[t]{4}{*}{1} & \multirow[t]{4}{*}{ CONTENTS } & $30-27$ & $\begin{array}{l}\text { EXCELLENT TO VERY GOOD: } \\
\text { related ideas }\end{array}$ \\
\hline & & $26-22$ & $\begin{array}{l}\text { GOOD: } \\
\text { ideas }\end{array}$ \\
\hline & & $21-17$ & $\begin{array}{l}\text { FAIR TO POOR: very often } \\
\text { unrelated ideas. }\end{array}$ \\
\hline & & $16-13$ & VERY POOR: irrelevant ideas \\
\hline \multirow[t]{4}{*}{2.} & \multirow[t]{4}{*}{ ORGANIZATION } & $20-18$ & $\begin{array}{l}\text { EXCELLENT TO VERY GOOD: } \\
\text { effective and incomplete }\end{array}$ \\
\hline & & $17-14$ & $\begin{array}{l}\text { GOOD: occasionally ineffective, } \\
\text { weak transition and incomplete } \\
\text { organization. }\end{array}$ \\
\hline & & $13-10$ & FAIR TO POOR: lack organization \\
\hline & & $9-7$ & $\begin{array}{l}\text { VERY POOR: litle or no } \\
\text { organization }\end{array}$ \\
\hline \multirow[t]{4}{*}{3.} & \multirow[t]{4}{*}{ VOCABULARY } & $20-18$ & $\begin{array}{l}\text { EXCELLENT TO VERY GOOD: } \\
\text { effective words choice }\end{array}$ \\
\hline & & $17-14$ & $\begin{array}{l}\text { GOOD: mostly effective words } \\
\text { choice }\end{array}$ \\
\hline & & $13-10$ & $\begin{array}{l}\text { FAIR TO POOR: frequently error in } \\
\text { word choice }\end{array}$ \\
\hline & & $9-7$ & $\begin{array}{l}\text { VERY POOR: mostly ineffective } \\
\text { word choice }\end{array}$ \\
\hline
\end{tabular}




\begin{tabular}{|c|c|c|c|}
\hline \multirow[t]{4}{*}{4.} & \multirow[t]{4}{*}{ LANGUAGE USE } & $25-22$ & $\begin{array}{l}\text { EXCELLENT TO VERY GOOD: } \\
\text { grammatically correct }\end{array}$ \\
\hline & & $21-18$ & $\begin{array}{l}\text { GOOD: mostly grammatically } \\
\text { correct }\end{array}$ \\
\hline & & $17-11$ & $\begin{array}{l}\text { FAIR TO POOR: frequently error in } \\
\text { grammar }\end{array}$ \\
\hline & & $10-5$ & $\begin{array}{l}\text { VEERY POOR: very often error in } \\
\text { grammar }\end{array}$ \\
\hline \multirow[t]{5}{*}{5.} & \multirow[t]{4}{*}{ MECAHANICS } & 5 & $\begin{array}{l}\text { EXCELLENT TO VERY GOOD: } \\
\text { few error in spelling, punctuation, } \\
\text { capitalization, paragraphing }\end{array}$ \\
\hline & & 4 & $\begin{array}{l}\text { GOOD: occosionally error in } \\
\text { spelling, punctuation, capitalization, } \\
\text { paragraphing }\end{array}$ \\
\hline & & 3 & $\begin{array}{l}\text { FAIR TO POOR: frequent errors in } \\
\text { spelling, punctuation, capitalization, } \\
\text { paragraphing }\end{array}$ \\
\hline & & 2 & $\begin{array}{l}\text { VERY POOR: dominated by errors } \\
\text { in spelling, punctuation, } \\
\text { capitalization, paragraphing. }\end{array}$ \\
\hline & TOTAL SCORE & & \\
\hline
\end{tabular}

After sobtaining the individual score of the two group. The writer processed the data score with the following steps to calculate the mean score of experimental group and control group.

1. Find out the mean score of experimental group:

Where:

$$
M x=\frac{\sum x}{N}
$$

$M x$ : is mean score of experimental group

$N$ : is the number of the sample

$\sum:$ is the sum of sigma

(Gay, 1990:298)

2. find our the mean of control group:

Where:

$$
\mathrm{My}=\frac{\sum y}{N}
$$

$\mathrm{Mx}$ : mean score of control group 
$\mathrm{N}:$ is the number of the sample (student)

$\sum y:$ is the sum all of the score

3. Regarding the teble of computing the devition of the two mean score, the writer also calculate square devition of the two score by using the following formulate:

$$
\sum x^{2}=\sum x^{2}-\frac{\left(\sum x\right)}{N} 2 \text { and } \sum y^{2}=\sum y^{2}-\frac{\left(\sum y\right)}{N} 2
$$

Where :

$X$ : the devition score of experimental group

Y: the deviation score of control group

$\mathrm{N}$ : the number of the sample

$\Sigma$ : the sum of sigma

4. Finding out the significant difference between students pre-test and post-test by using formula:

Where:

$$
\mathrm{t}=\frac{M_{x-M_{y}}}{\sqrt{\left(\frac{\Sigma x^{2}+\Sigma y^{2}}{N x+N y-2}\right)\left(\frac{1}{N x}+\frac{1}{N y}\right)}}
$$

M: mean deviation of each group

$\mathrm{N}$ : subject of sample

$\mathrm{X}$ : deviation between pre-test and pos-test (experimental group)

Y: deviation between pre-test and post-test (control group)

$\sum$ : the sum of

$d f: \mathrm{Nx}+\mathrm{Ny}-2$ (degree of freedom)

(Arikunto,2010:306)

\section{FINDING AND DISCUSSION}

\section{Findings}

In this case, the analysis of the data is devided into two part by asking the students to compose essay whather this technique has effect or not in students'writing descriptive text. To get the data, the writer conducted tha research in May 2015.

In the first test (pre-test), students were asked to make a descriptive text about Ampenan Beach followed by the correct generic structure and linguistic features. And the second test (pos-test), was asked to compuse a descriptive text about $\mathrm{Al}$ Gazali followed by the correct generic structure and linguistic features. After the obtaining the data of the students score, the writer presents the data as follow: 
Table 01. Table of Final Score of Experimental Group (x)

\begin{tabular}{|c|c|c|c|}
\hline \multirow[b]{2}{*}{ No. } & \multirow[b]{2}{*}{ Name } & \multicolumn{2}{|c|}{ Score } \\
\hline & & Pre-test & Pos-test \\
\hline 1. & ADI & 50 & 78 \\
\hline 2. & AS & 45 & 72 \\
\hline 3. & DI & 35 & 75 \\
\hline 4. & DS & 50 & 80 \\
\hline 5. & ES & 45 & 70 \\
\hline 6. & $\mathrm{H}$ & 40 & 75 \\
\hline 7. & $\mathrm{HH}$ & 50 & 80 \\
\hline 8. & I & 45 & 75 \\
\hline 9. & IJ & 35 & 70 \\
\hline 10. & HR & 40 & 75 \\
\hline 11. & IF & 48 & 70 \\
\hline 12. & RA & 50 & 78 \\
\hline 13. & $\mathrm{~N}$ & 57 & 70 \\
\hline 14. & $\mathrm{~N}$ & 45 & 75 \\
\hline 15. & NI & 45 & 75 \\
\hline 16. & $\mathrm{AE}$ & 41 & 70 \\
\hline 17. & DPS & 45 & 72 \\
\hline 18. & MR & 35 & 80 \\
\hline 19. & LHG & 45 & 75 \\
\hline 20. & ER & 55 & 78 \\
\hline
\end{tabular}




\begin{tabular}{|l|c|c|}
\hline Total & 840 & 1496 \\
\hline
\end{tabular}

From the table, it can be seen that the result post-test of the students experimental groups which has been treated by using "autentic materials" was better (1510) than the result of pre-test (840).

Table 02. Table of Final Score of Control Group

\begin{tabular}{|c|c|c|c|}
\hline \multirow[b]{2}{*}{ No. } & \multirow[b]{2}{*}{ Name } & \multicolumn{2}{|c|}{ Score } \\
\hline & & Pre-test & Pos-test \\
\hline 1. & MFM & 50 & 50 \\
\hline 2. & MIT & 30 & 40 \\
\hline 3. & MIA & 35 & 40 \\
\hline 4. & $\mathrm{MH}$ & 35 & 45 \\
\hline 5. & $\mathrm{M}$ & 45 & 50 \\
\hline 6. & MD & 40 & 50 \\
\hline 7. & MA & 50 & 60 \\
\hline 8. & MI & 35 & 40 \\
\hline 9. & MRE & 40 & 45 \\
\hline 10. & MAR & 45 & 50 \\
\hline 11. & $\mathrm{R}$ & 30 & 40 \\
\hline 12. & $\mathrm{SF}$ & 35 & 45 \\
\hline 13. & M & 45 & 55 \\
\hline 14. & $\mathrm{HF}$ & 50 & 55 \\
\hline 15. & MDA & 50 & 60 \\
\hline 16. & LHA & 40 & 45 \\
\hline
\end{tabular}




\begin{tabular}{|l|l|l|l|}
\hline 17. & $\mathrm{R}$ & 35 & 40 \\
\hline 18. & $\mathrm{R}$ & 40 & 50 \\
\hline 19. & $\mathrm{~S}$ & 40 & 45 \\
\hline 20. & MF & $50 \quad$ & 55 \\
\hline \multicolumn{2}{|l|}{ Total } & 820 & 965 \\
\hline
\end{tabular}

From the table, it can be the result of the students control groups was increased, the result of pre-test (820) and post-test (965). So, the result of experimental groups was better than the result of control groups. It meant, authentic materials could improve student's writing ability.

\section{Calculating the Students Mean Score of Two Groups}

To got mean score of two groups in this investigation, the writer applied the following formula:

Where:

$$
M x=\frac{\sum x}{N}
$$

$M x:$ the mean score of experimental group

$N$ :the number of the sample

$\sum:$ the sum of sigma

For this purposes, the writer tabulated the individual score of each group as shown in the table bellow:

Table 03. Table of student's individual deviation score from the mean score of experimental group $(\mathrm{x})$ :

\begin{tabular}{|c|c|c|c|c|}
\hline \multirow{2}{*}{ No. } & \multicolumn{2}{|c|}{ Score } & \multirow{2}{*}{$\mathrm{X}^{1}$} & \multirow{2}{*}{$\mathrm{X}^{2}$} \\
\cline { 2 - 3 } & $\mathrm{X}_{\mathrm{a}}$ & $\mathrm{X}_{\mathrm{b}}$ & & \\
\hline 1. & 50 & 78 & 28 & 784 \\
\hline 2. & 45 & 72 & 27 & 729 \\
\hline 3. & 35 & 75 & 40 & 1600 \\
\hline 4. & 50 & 80 & 30 & 900 \\
\hline 5. & 45 & 70 & 25 & 625 \\
\hline 6. & 40 & 75 & 35 & 1225 \\
\hline 7. & 50 & 80 & 30 & 900 \\
\hline 8. & 45 & 75 & 30 & 900 \\
\hline 9. & 35 & 70 & 35 & 1225 \\
\hline
\end{tabular}




\begin{tabular}{|c|c|c|c|c|}
\hline 10. & 40 & 75 & 35 & 1225 \\
\hline 11. & 48 & 70 & 22 & 784 \\
\hline 12. & 50 & 78 & 28 & 784 \\
\hline 13. & 57 & 70 & 28 & 784 \\
\hline 14. & 45 & 75 & 30 & 900 \\
\hline 15. & 45 & 75 & 33 & 1089 \\
\hline 16. & 41 & 70 & 29 & 841 \\
\hline 17. & 45 & 72 & 27 & 729 \\
\hline 18. & 35 & 80 & 45 & 1225 \\
\hline 19. & 45 & 75 & 25 & 625 \\
\hline 20. & 55 & 78 & 13 & 169 \\
\hline Total & 840 & 1496 & 560 & 18043 \\
\hline
\end{tabular}

In which:

$\mathrm{Xa}:$ Pre-test

$\mathrm{Xb}$ : Post-test

$\mathrm{X}^{1}$ : Deviation score obtained score from pre-test and post-test

$\mathrm{X}^{2}$ : Square of deviation score

After getting the deviation score pre-test and post-test, the mean score of two groups computed, that was dividing the total deviation score in the group. It was a formulated as follow:

Mean of deviation score of experimental group ( $\mathrm{Mx})$ in table 4.3 above it was identified that:

$$
\begin{aligned}
\sum x & : 670 \\
\mathrm{~N} & : 20 \\
M x & =\frac{\sum x}{N} \\
= & \frac{560}{20} \\
= & 28
\end{aligned}
$$

Table 04. Table of student's individual deviation score from the mean score of control group (y):

\begin{tabular}{|c|l|l|l|l|}
\hline \multirow{2}{*}{ No. } & \multicolumn{2}{|c|}{ Score } & \multirow{2}{*}{$\mathrm{Y}^{1}$} & \multirow{2}{*}{$\mathrm{Y}^{2}$} \\
\cline { 2 - 4 } & \multicolumn{2}{|c|}{$\mathrm{Y}_{\mathrm{a}}$} & \multicolumn{1}{|c|}{$\mathrm{Y}_{\mathrm{b}}$} & \\
\hline 1. & 50 & 50 & 0 & 0 \\
\hline 2. & 30 & 40 & 10 & 100 \\
\hline
\end{tabular}




\begin{tabular}{|c|l|l|l|l|}
\hline 3. & 35 & 40 & 5 & 25 \\
\hline 4. & 35 & 45 & 10 & 100 \\
\hline 5. & 45 & 50 & 5 & 25 \\
\hline 6. & 40 & 50 & 10 & 100 \\
\hline 7. & 50 & 60 & 10 & 100 \\
\hline 8. & 35 & 40 & 10 & 100 \\
\hline 9. & 40 & 45 & 5 & 25 \\
\hline 10. & 45 & 50 & 5 & 25 \\
\hline 11. & 30 & 40 & 10 & 100 \\
\hline 12. & 35 & 45 & 10 & 100 \\
\hline 13. & 45 & 55 & 10 & 100 \\
\hline 14. & 50 & 55 & 5 & 25 \\
\hline 15. & 50 & 60 & 10 & 100 \\
\hline 16. & 40 & 45 & 5 & 25 \\
\hline 17. & 35 & 40 & 5 & 25 \\
\hline 18. & 40 & 50 & 10 & 100 \\
\hline 19. & 40 & 45 & 5 & 25 \\
\hline 20. & 50 & 55 & 5 & 25 \\
\hline Total & 820 & 965 & 145 & 1225 \\
\hline & & & &
\end{tabular}

In which:

Ya : Pre-test

$\mathrm{Yb}:$ Post-test

Y1 : Deviation score obtained score from pre-test and post-test $\mathrm{Y}^{2}$ : Square of deviation score.

Mean of deviation score of control group (My) in table 4.4 above it is identified that:

$$
\begin{aligned}
& \text { My }=145 \\
& N=20 \\
& \begin{array}{c}
M y=\frac{\sum y}{N} \\
=\frac{145}{20} \\
=7,25
\end{array}
\end{aligned}
$$

The mean score of deviation score experimental group in this study was better than the mean score of control group. It clearly indecated that the students of 
experimental groups did the test much better than the students control groups. Since the materials of the test have been presented to the two groups by the same the teacher and in the same lenght of time, it has successfull in the test. In this case, it could said that authentic materials can increase writing ability.

\section{Calculating the Student's standar Deviation of the Two Group}

To calculate the student's standars deviation of two group, the following formula was applied:

Square deviation of experimental group in the table 4.3 above, it was identified that:

$$
\begin{aligned}
& \sum X^{2}=18043 \\
& N=20 \\
& \sum x^{2}=\sum x^{2}-\frac{\left(\sum X\right)}{N} 2 \\
&=18043-\frac{(560)}{20} 2 \\
&=18043-15680 \\
&=2363
\end{aligned}
$$
that:

Square deviation of control group in the table 4.4 above, it was identified

$$
\begin{aligned}
\sum y^{2} & =\sum y^{2}-\frac{\left(\sum x\right)}{N} 2 \\
& =1225-\frac{(145)}{20} 2 \\
& =1225-1051,25 \\
& =173,75
\end{aligned}
$$

\section{Computation and Analysis of Significance the Mean Score Deviation}

Looking at the result of mean score two group obtained through statical computation. Theoritacally, however, the significance of the deviation two mean scores were compared to measure whether the deviation was significance or not.

This formula is used to compute, follow: 


$$
\begin{aligned}
\mathrm{t} & =\frac{M_{x-M y}}{\sqrt{\left(\frac{\Sigma x^{2}+\Sigma y^{2}}{N x+N y-2}\right)\left(\frac{1}{N x}+\frac{1}{N y}\right)}} \\
& =\frac{28-7,25}{\sqrt{\left(\frac{2363+173,75}{20+20-2}\right)\left(\frac{1}{20}+\frac{1}{20}\right)}} \\
& =\frac{20,75}{\sqrt{\left(\frac{2536,75}{38}\right)\left(\frac{2}{20}\right)}} \\
& =\frac{20,75}{\sqrt{(66,75)(0,1)}} \\
& =\frac{20,75}{\sqrt{6,675}} \\
& =\frac{20,75}{2,58} \\
& =8,042
\end{aligned}
$$

\section{Discussion}

Now the writer found the score of t-test. Next, comparing the two critical values: $\mathrm{t}$-test and t-table. Before it was consulted to the table of the $\mathrm{t}$ distribution. Firstly, the writer determined the degrees of freedom (df) that is $\mathrm{N}$ $\mathrm{x}+\mathrm{Ny}-2=38$. According to Sugiyono (2014) for the degree of freedom 38 the convidence level of $95 \%(0,05)$ equal to 2,042 and convidence level of $99 \%$ $(0,01)$ equal to 2,750 . The comparison was done between t-test formulas with ttable in which the result of t-test was 8,042 . It was found out that the table of $t$ indicated:

$0,05=$ t-test with $8,042>$ t-table 2,042 (95\%)

$0,01=$ t-test with $8,042>$ t-table 2,750 (99\%)

It mean that the study indicated degree of difference between two score was significant for both cofidence level. In other words, based on the result of comparing t-test and t-table with df 0,05 gained $95 \%$ and df 0,01 gained $99 \%$, the authentic materials have effect in teaching descriptive text toward students' writing ability. 
The finally, the writer concluded that, authentic materials is effective in teaching descriptive text toward students' writing ability. So, the writer declared that the treatment was significance and have positive effect in students writing ability.

Based on the research, the students' writing descriptive text ability by using authentic materials. It shown, where the t-test was higer than t-table, with the degree of freedom used in the research is interpreted by comparing the two critical values: $t$-test and t-table. The degree of freedom (df) that writer used was 38 , so the df is 2,750 for confidence level of $0,01(99 \%)$.

Table 4.5

The Comparision Between the t-test and t-table

\begin{tabular}{|c|c|c|c|}
\hline t-test & Df & \multicolumn{2}{|c|}{ t-table } \\
\hline \multirow{2}{*}{8,042} & \multirow{2}{*}{38} & 0,05 & 0,01 \\
\cline { 3 - 4 } & & 2,042 & 2,750 \\
\hline
\end{tabular}

The table 4.5 above shows that with degree of freedom of 38 , which is gained from the formula from the formula $\mathrm{Nx}+\mathrm{Ny}-2=38$, the critical value of t-table at significance level of $0,01(99 \%)$ was 2,750 . It could be said that the results of using authentic materials significant in teaching and learning writing descriptive text. It can be show by this table that $t$-test $\geq t$-table. It indicates that students in experimental group who were treated by using authentic materials is getting significant writing descriptive text ability than students in control group who were not treated by using traditional method.

Consequently, since the pre-test $(8,042)$ was higher than the t-table at both significance level $(2,750)$, the Null Hypothesis (Ho) which states, “ authentic materials is not effective in teaching descriptive text toward students ability" is rejected, so the alternative Hypothesis (Ha) which states that" authentic materials is effective in teaching descriptive text toward students writing ability" is accepted.

The writer made discussion by using authentic materials in teaching writing. It can increase the students' writing ability in descriptive text, it caused:

1. Can stimulate and motivate students to became express themselves, because in the classroom it's the using of authentic materials in teaching and learning proses is more interest. 
2. Can made students better in imagine the topic which they want to write, because authentic materials can bring the students in the real situation based on the topic.

This result increasing proved that authentic materials is effective in teaching descriptive text toward students' writing ability at MTs Nurul Jannah NW Ampenan in academic year 2014/2015.

When the writer did the research, the writer found that the students' face some difficulties in writing descriptive text, there are:

1. Content : Students' understanding in the content of text is very low when a teacher using a traditional method in learning process but, when teacher using authentic materials, some of the sudents began to know what the content of the text. Which the role of content is how to analyze students' ideas or an unterstanding of the text.

2. Organization : In this aspect, the students must organize their ideas appropiate the structure and grammar. Students' ability in organizing a descriptive text is very low. Almost all of them did not know how to start arrange descriptive text, but after teacher using authentic materials as a media, the students' ability in organizing descriptive text increas. They can begin arrange descriptive text more easily.

3. Vocabulary : Firstly, students face difficulties, when they want to write descriptive text because they lack of vocabularies. As we know that vocabulary is one of the most important aspect in writing. If they have enough vocabulary, they can write a good descriptive text. Finaly, after the teacher using authentic materials the students step by step wrote desciptive text with a good vocabularies because authentic materials help them to decide what kind of vocabulary that must be used.

4. Language Use : Students' ability in language use in writing descriptive text is very bad, almost of students did not know what kind of language use that must be used which appropreate with the grammatcal of the text, but after the teacher usung authentic materials as a media the students ability in language use improve. They can chose what kinf of words that related to the content of sentences and text they supposed to write down.

5. Mechanics : Students' ability in writing descriptive text is very bad, especially in writing descriptive text systematically. Almost of them did not have any ideas about how the systematic structure of descriptive text, some of them have errors in spelling, punctuation and capitalization. But after the teacher used authentic materials as media, the students getting better in understanding the characteristics and structure of descriptive text. 


\section{CONCLUSION AND SUGGESTIONS}

After getting the result of this investigation, the result showed that the mean score was 28 for experimental group and mean score was 7,25 for control group. The standard deviation was 2363 for the experimental group and standar deviation was 173,75 for control group. Another result obtained through analysis of the data was value of t-test 8,042 while the value t-table 2,750 This has been cheecked in the table of discrimination of the value. This figure indicated that the value of t-test was higher than the value of $t-$ table.

Based on the analysis data above, the writer found that the result of t-test was higher than t-table. This mean that the null hypothesis (Ho) which said, "authentic materials not effective was rejected, while the alternative hypothesis (Ha) which said, "authentic materials is effective in teaching descriptive text toward student' writing ability" was accepted.

Finally, based on explanation above, the writer can conclude the use of authentic materials has effect especially in increase student's writing ability.

\section{REFERENCES}

Arikunto. (2010). Procedur Penelitian Suatu Pendekatan Praktek: Jakarta. PT. Reneka Cipta.

Brown,H.D. (2001). Teaching by Principles An Intractive Approach to Language Pendagogy $\left(2^{\text {nd }} E d s\right)$. New York: Addition Wesley Longman, Inc.

Chavez. (1998). Learnenr's Perspective on Authenticity. New York: Addison Wesley Longman.

Fauziati, Endang. (2008). Teaching of English As A Foreign Language (TEFL). Surakarta: Muhammadiyah University Press.

Guariento, W. \& Morley,J. (2001). Text And Task Authenticity in the EFL Classroom. Oxford University Press: ELT Journal. Vol: 55/4

Harsyaf. Nurmaini,M.Y. \& Izmi, Zakhwan. (2009). Teaching Writing. Jakarta: Ministry of National Education.s

Richards,C.J. \& Willy A. Renandya.(2002). Methodology in Language

Teaching: An Anthology of Current Practice. New York: Cambrige University Press.

Putri,N.W. (2009). A Thesis:The Effectiveness of Using Picture Series in Writing Descriptive Paragraph: A Case Study at the Second Year Student of SMP Al-Ikhlas Taliwang Academic year 2008/2009. Muhammadiyah Unive rsity of Mataram: Unpublished

Rafi'ah. (2014). A Thesis:The Use of Descriptive Text to Develop Students' Writing Skill; An Experimental Study at Second Year Sudents of SMPN 1 Labuapai in 
Academic year 2014/2015. Muhammadiyah University of Mataram: Unpublished.

Sugiyono. (2014). Metode Penelitian Pendidikan (Pendekatan Kualitatif, kuantitatif, dan $R \& D)$. Bandung: Penerbit Alfabeta.

Taylor, D. 1994. Inauthentic Authenticity or Aunthenticity Inauthentic?. Oxford: Oxford Univercity Press.

Zurkarnain. (2014). A Thesis: The Use of Authentic Materials to Increas Student Writing Ability in Procedural Text for the Seventh Grades Student of MTs. Nurul Islam Ganti in Academic Year 2014/2015. Muhammadiyah University of Mataram: Unpublished. 